\title{
On Higher Education
}

Transformation

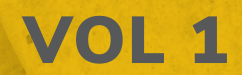

\section{SCHOLARLY \\ ENGAGEMENT AND \\ DECOLONISATION}

Editors:

M Crul, L Dick, H Ghorashi \& A Valenzuela Jr

Views from South Africa,

The Netherlands and the United States 


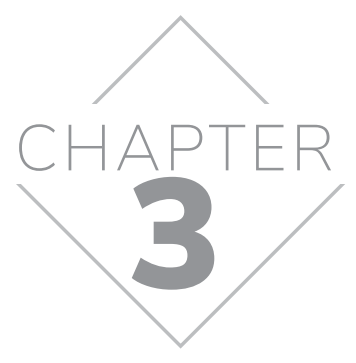

\title{
On 'brick walls' and other Black decolonial feminist dilemmas
}

\section{Anger and racial diversity in universities}

\author{
Shirley Anne Tate
}

\begin{abstract}
I am a "wounded body stranger" (Tate \& Wahidin, 2014) removed from myself so I do not feel psychic pain. However, pain emerges, and I use it here drawing from Audre Lorde's The Cancer Journals as an analytic frame to explore how as Black women we cope with an imposed silencing from within white feminism whilst maintaining subjective and Black feminist community cohesiveness. I look at psychic institutional pain in UK universities as locations of body and knowledge estrangement drawing on Toni Morrison's Playing in the Dark and such pain is seen as both repressive and productive of Black feminist critique. Institutional pain can also be agentic, productive, when we notice that it is rooted in Lorde's anger. 'Mi vex' recognises the source of vexation, of Black feminist anger-pain, while repeating it as complaint and need for intersectional political action in order to continue to build Black feminist community.
\end{abstract}

Keywords: affect; anger; Black feminist; pain; institutional racism 


\section{SCHOLARLY ENGAGEMENT AND DECOLONISATION}

\section{INTRODUCTION}

In higher education institutions the promise of diversity is social justice transformation through changes to policy, practice, culture, process and institutional structure. This promise has built a diversity community of activists, academics and practitioners even though diversity is a 'non-performative' (Ahmed, 2006, 2012). Diversity builds community through generating a feeling of 'joy' (Lorde, 1980) that something can be done to radically change institutions and societies. However, diversity's ability to build community through its 'erotic life' (Lorde, 1980) also has a side marked by grief and grievance within universities. This side is what Sara Ahmed (2012) calls 'brick walls' which are mobilised by and mobilise the negative affect of anger. In order to engage with an analysis of anger from a Black decolonial feminist perspective, the discussion in this chapter focuses on the trope of 'the angry Black woman' within predominantly white higher education institutions. These universities are already diversity aware as seen through their policies, but are also diversity averse as we can see from the lived experiences of Black women academics who experience these environments as toxic. Drawing on narratives from Black female academics within UK universities and auto-ethnography, the discussion shows that even though predominantly white universities' institutional culture is anger averse, this culture reproduces 'the angry Black woman' as part of its racist microaggressions. As such, Black women's anger must be understood as (re)produced by anti-black woman racism in higher education institutions. Thus, anger can be redefined as psychic institutional pain rather than something inherent within Black women. A Black decolonial feminist analysis would regard such anger as productive and agentic because it is rooted in experiences of, and responses to, racialised gender injustice. Recognising anger as productive and agentic enables diversity to become performative in terms of anti-racist social justice transformation within universities. This is the case because such recognition focuses attention on the impact of racism on Black women faculty through white supremacy's construction of 'the angry Black woman'. Let us now turn to look at 'the angry Black woman' and her construction. 


\section{THE ANGRY BLACK WOMAN: WHO CONSTRUCTS US?}

For Jamaican Black decolonial feminist philosopher and cultural theorist, Professor Emerita Sylvia Wynter OJ':

You cannot solve the issue of 'consciousness' in terms of their body of knowledge. You just can't. Just as within the medieval order of knowledge there was no way in which you could explain why it is that certain planets seemed to be moving backwards. Because you were coming from a geocentric model, right? So you had to 'know' the world in that way. Whereas from our 'Man-centric' model, we cannot solve 'consciousness' because Man is a purely ontogenetic/purely biological conception of being, who then creates 'culture'. So if we say consciousness is constructed who does the constructing? You see? (Thomas, 2006:2).

Here Wynter alerts us to the danger of continuing to see the world through the eyes of white, Western man. In common with Yuderkys Espinosa Miñoso (2007), I would like to add white, Western woman here so I will change Wynter's (2006) statement to (Wo)Man and (Wo)Man-centric. I want to pause and look in a little more detail at the issue highlighted by Wynter - who constructs consciousness and culture? This is necessary if we want to get to grips with how it is that we still struggle within feminism over the (Wo)Mancentric construction of Black women's consciousness. As well as this, staying with the theme of anger, I want to specifically remember our socio-cultural construction as the always already 'angry Black woman' who is inherently defensive. It is particularly important to look at the psychic life and material effects of this white (Wo)Man construction of our anger as a prelude to its decolonisation. A Black decolonial feminist perspective enables us to construct alter/native (Truillot, 1995) consciousness and culture. For our purposes here, it is about thinking about anger-pain, spoken as complaint rather than grief (Cheng, 2010), as an analytic tool for decolonising feminist (Wo)Man's antiBlack woman knowledge, attitude, affect, practice and constructions. Let us begin with an example of the somatisation of institutional anger-pain in my moment of weakness revealed, my confession of imperfection:

I grind my teeth. I grind my teeth so much that they hurt. My dentist says that it is because the ligaments in my teeth never get a chance to rest because my jaw is constantly clenched when I sleep. So now I wear a soft of Jamaica) which is the fourth highest national honour for services in the fields of education, history and culture. 


\section{SCHOLARLY ENGAGEMENT AND DECOLONISATION}

\section{gum shield at night for protection. I need to protect my body from being attacked by itself, by myself. This speaks a daily estrangement from myself in White feminist institutional spaces of alienation and psychic pain. I am a 'wounded body stranger' (Tate \& Wahidin, 2013) removed from myself so I do not feel psychic institutional pain.}

However, pain emerges, and I use it here as an analytic frame to explore how, as Black women academics, we cope with an imposed silencing from within white feminism whilst maintaining personal cohesiveness. As both repressive and productive of Black decolonial feminist critique in those spaces of alienation that are UK universities, psychic institutional pain can also be agentic when we notice that it is rooted in anger at racist injustice. I can only reach back to my Jamaican origins, my language, to the phrase 'mi vex' to speak such deep vexation which is not contained in the English word 'anger'. Anger speaks of an individual failing whereas ' $m i$ vex' recognises the source of vexation, of Black decolonial feminist anger-pain as being without our bodies. 'Mi vex' implicates anger as relational, as not being essentially part of us. Anger comes from elsewhere but is 'affecting' because of its intensity (Brennan, 2004; Gutíerrez Rodríguez, 2010). 'Mi vex' repeats this affection, this vexation as a complaint and need for feminist/ anti-racist / queer / anti-ableism/ anti-ageism / anti-gender binary / anti-class discrimination / anti-capitalist politics to continue to build an inclusive Black decolonial feminist community. A Black decolonial feminist perspective acknowledges the embeddedness of the coloniality of affect, power, gender, knowledge and being 'the angry Black woman' within the white supremacist construction. It is a construction which seeks to alienate Black women from themselves and each other through the psychic pain generated within institutions since Black female academics are interpellated as 'angry'. Through its affection, anger as psychic institutional pain spreads like an invisible net across institutions impressing itself on Black women as it passes by. Thus, it is that 'mi vex' as Black decolonial feminist complaint speaks against the affection of anger as psychic institutional pain which attempts to alienate one from oneself and others.

\section{PSYCHIC INSTITUTIONAL PAIN AND ALIENATION}

My teeth grinding shows that there is a somatic location to my psychic institutional pain. It is transferred to my teeth. It is my teeth that feel terror, 
unhappiness, loneliness and dread as my heart refuses to cope with this psychic burden made flesh for fear it will burst open. My teeth are the physical location within my body of the alienation of being set apart, caused by white feminist racism and its exclusionary affective relationalities within university spaces. We should remember that being set apart refers to both physical exclusion, intellectual marginalisation and erasure within contexts in which (Wo)Man is institutionally dominant. In these contexts, the liberation of Black decolonial feminist thought is marginalised within the feminist canon and there is also exclusion of myself, my body, from white feminist conviviality in UK universities.

I do not grind my teeth because I was born a teeth grinder, but because I have been made into one. I have been made into one because of the anger I feel working in a white institution in, with and through the pain produced by the negative affective and material effects of racism and heteropatriarchy. The pain of gritting your teeth so hard that your jaw hurts, the pain of being silenced personally, politically and epistemologically, the pain of solitude, of being utterly alone in your conviction that racist injustice occurred, the pain which emerges through your fear of ostracism and its actual occurrence. Here is one example of why I grind my teeth:

The Head of Department is a white feminist who sees feminism as a point of commonality between you. You work with colleagues for months on developing a proposal for a new academic area on racism, critical ethnic, critical whiteness and decolonial studies. You have been told there will be four academic areas. Other colleagues in the department compliment your group's proposal and use it as a template to develop their own. However, your proposal is rejected. By senior management team fiat, four academic areas become three. In one fell swoop work on racism/decolonial theory/ critical ethnic studies/critical whiteness studies has been eradicated from the department without any question being asked by the wider faculty, without open discussion or intellectual debate. What do you think of 'feminist sisterhood' now, a 'feminist sisterhood' which in fact speaks openly about the need to 'get people out of bunkers'? Interesting isn't it how when you work on anything in university spaces to do with critiquing white supremacy you are in a bunker? 


\section{SCHOLARLY ENGAGEMENT AND DECOLONISATION}

Speaking out of that bunker created for Black women and myself by this white feminist's use of white privilege and institutional white power, 'no wonder mi vex'! My anger is one that burns hot, hard and deep, and it is one that I freely admit I have carried with me for years because of the experiences of other Black women and those that are my own. It is reignited when new racist injustices emerge to remind me that there is no such thing as tolerance and if it did exist it would be based on my being tolerated by a whiteness, by a (Wo)Man-ness which ignores that it is in itself intolerable. To say 'mi vex' makes such white supremacist tolerance intolerable because it produces anger transposed to my teeth grinding because of the daily white supremacy induced pain I encounter in white institutions. I say 'white supremacy induced' here to show that I am not inherently angry. Rather, like other Black women, anger emerges at racist injustice. In white institutions, my thoughts have been stolen, my body vilified, my presence only heard through the voice of 'the angry Black woman' who can't help but be 'defensive'. 'The angry Black woman' continues to be (re)constructed and circulated institutionally by white supremacy as a prelude to the erasure of Black decolonial feminist critique. 'The angry Black woman' is part of anti-Black woman racism's erotic life within UK universities.

The 'erotic life of racism' (Holland, 2012) in institutions continues to produce "racialising assemblages" (Weheliye, 2014) as 'the angry Black woman' becomes 'flesh' (Spillers, 2003). The pain of the anger produced by white feminist anti-Black woman racism enables a move away from the violence of 'feminist sisterhood'. This 'move away from' white feminist violence occurs because

... the most essential aspect of pain is its sheer aversiveness [...] the very
content of pain is itself negation. If to the person in pain it does not feel
averse, and if it does not in turn elicit in that person aversive feelings
towards it, it is not in either philosophical discussions or psychological
definitions of it called pain. Pain is a pure physical experience of negation,
an immediate sensory rendering of 'against', of something being against
one and of something one must be against. Even though it occurs within
oneself, it is at once identified as 'not oneself', 'not me', as something so
alien that it must right now be gotten rid of (Scarry, 1985:52).

To become myself I must refuse psychic institutional pain's negation. I must refuse anger's negation because it is part of "the coloniality of power" (Quijano, 2000). To rid myself of this anger is in itself liberating because it roots me 
elsewhere, an elsewhere with a background, an elsewhere which removes me from the 'flesh' of the Middle Passage and enslavement (Spillers, 2003). This is an elsewhere not dependent on the "philosophies of the One in the West" (Glissant, 1997) to come into being as an individual. I become myself outside of the gaze of white feminist (mis)recognition of 'the angry Black woman'. Refusing white feminist induced psychic institutional pain is necessary for personal freedom because this pain which makes me grind my teeth produces

... an almost obscene conflation of private and public. It brings with it all the solitude of absolute privacy with none of its safety, all the self-exposure of the utterly public with none of its possibilities for camaraderie or shared experience (Scarry, 1985:53).

Anti-Black woman racism's construction of 'the angry Black woman' as unasked for solitude and unsolicited self-exposure, mean that our Black women's bodies are constantly overlain by Frantz Fanon's (1986) colonial masks within universities. In this case, the colonial mask is that of 'the angry Black woman'. I will be against that stereotype as much as it is against me. I will see it as not me, as abject. I will eject it from myself. Saying 'mi vex' enables me to rid myself of this psychic institutional pain because it returns me to who I am. It returns me to a Black decolonial feminist community; to Caribbean decolonial feminist thought (Reddock, 2007); to Marcus Garvey's (2016) Black Nationalism; to Fanon's (1986) decolonisation of the colonial psyche; to Walter Rodney's (1986) Black Power; to Jamaica's Nanny as a guerrilla fighter, a Maroon chief fighting against British colonialism and enslavement. It seems to me that white feminism seeks to limit Black women academics' field of vision within a UK internal racial colony which lives on in universities, white feminist knowledge and curricula in which Black decolonial feminist thought is present for one week's teaching, if at all. These are some of the reasons why 'mi vex'.

However, I am tired of only being able to express my anger at such racist injustice in the solitude of teeth grinding while I sleep. My gum shield has taught me that anger should not and indeed, cannot be ignored. Instead, I should say 'mi vex' and, take up Lorde's (2007 a, b, c) scholarship on angerpain as transformative forces in and against 'white feminist sisterhood' and heteronormative patriarchy. Let us look to first Toni Morrison (1992) and then Audre Lorde (1980; 2007 a, b, c) to break the silencing of the institutional anger- 


\section{SCHOLARLY ENGAGEMENT AND DECOLONISATION}

pain of racism and to engage Black decolonial feminist politics by speaking anger as complaint against white supremacist feminism.

\section{FROM COMPLAINT TO ACTION}

When I first read Playing in the Dark (Morrison, 1992) all those years ago, I felt supported in my nascent view that 'race' and whiteness are consistent themes in writing even when and perhaps especially if they are not mentioned. Morrison's work still makes sense to me in the $21^{\text {st }}$ century because of its resonance with my thinking on 'race'. As a Jamaican immigrant to the UK, the foundations of this thinking are influenced by Fanon's (1986) work in Black Skins, White Masks on the colonial psyche; Rastafarianism (Chevannes, 1994), a Jamaican nationalism that was about carving a Black nation out of plurality and mixedness post-independence (Thomas, 2004); Rodney's (1986) Caribbean Black Power and Black decolonial feminist thought which includes Caribbean and Black Latin American feminisms. These, for me, were about explication of the colonial condition and building toward a Black Atlantic diasporic political, social and cultural future.

Morrison's work was crucially about how, as a Black decolonial feminist academic, it is necessary to look to develop Black anti-racist feminist critique in conditions of academic (un)freedom. She outlined her project as "an effort to avert the critical gaze from the racial object to the racial subject, from the described and imagined to the describers and imaginers, from the serving to the served" (Morrison, 1992:90). Thus, this critical gaze was a decolonial one in its focus on dismantling "racialising assemblages" (Weheliye, 2014). Here, the former certainties within the 'feminist sisterhood' of necessity must be given up for critical examination and transformation. Focusing on racialising assemblages also meant putting knowledge generated by Black women at the forefront of scholarship making them/us subjects who describe, imagine and are served.

Playing in the Dark presented my task as a Black decolonial feminist as two-fold. I had to both decentre whiteness as subject, process, structure, psyche and sociality and look at blackness and whiteness to see who this racial subject could be. This look though was now from the very critical Black decolonial feminist lens given to me by Morrison's work rather than one only based on excavating Black women's experience and knowledge and bringing 
these to light. I was rather much more interested in how Black women as subjects describe, imagine and position themselves in those putatively 'postrace' (Goldberg, 2015) societies in which 'race' still matters. This is so, as it seemed, that much had to be said about how it is that racial objects become 'raced', gendered, able-bodied, classed and sexualised subjects through Black decolonial feminist politics, racialised gender imaginaries and everyday 'raced' gender performativity. Of further interest is how we, in turn, imagine and describe Black Atlantic diasporic Black womanhood as community, affect and skin; how such community can be inclusive or exclusionary, as well as how it is that we continue to position ourselves as Black within the proliferation of difference. I have always heeded Morrison's (1992:8) warning that we should not replace dominant Eurocentric scholarship and discourses with dominant Afrocentrism and attended to what she says about getting out of that bind. To quote her:

I do not want to encourage those totalizing approaches to AfricanAmerican scholarship which have no drive other than the exchange of dominations-dominant Eurocentric scholarship replaced by dominant Afrocentric scholarship. More interesting is what makes intellectual domination possible; how knowledge is transformed from invasion and conquest to revelation and choice; what ignites and informs the literary imagination and what forces help establish the parameters of criticism (Morrison, 1994:8, [My italics]).

With these words, she sets out the challenge for Black decolonial feminist scholarship as being that of critiquing colonial power relations in the academy, in publishing and the public sphere. This is necessary because colonial power relations still determine what counts as knowledge worthy of dissemination and citation, as well as which knowledge can build the disciplinary canon. She also shows that even knowledge linked to what she calls 'invasion and conquest' can be used in Black decolonial feminist critique to produce new meanings. Thus, one should not start uncritically from the established white feminist canon, but should bring subjugated knowledge to light within the academy. Critique, including self-critique, is significant in Black decolonial feminist politics as it should be a perspective that seeks to counter dominant intersectional racialised gender narratives. This has been the academic task laid down by her work for Black decolonial feminist critique which means that whether we are readers or writers, as critics we must not remain "too polite or too fearful to notice a disrupting darkness before [our] eyes" (Morrison, 1992:91). 


\section{SCHOLARLY ENGAGEMENT AND DECOLONISATION}

As critics, it is too easy to turn away from noticing disruptions of the takenfor-granted when fear acts to silence us. Fear of being wrong, fear of being an outsider, fear of being ridiculed, fear of being seen to not be political or conscious enough as Black women, fear of being cast as 'the angry Black woman', or fear of being placed 'in a bunker'. Fear is an immobilising affect, but one that must be dealt with if we are to endeavour to think a Black decolonial feminism that recognises and gives a place to the differences of class, sexuality, mixedness, gender, age, ability and location, for example. We must get over our fear to explore how it is that we can still maintain Black decolonial feminist politics as a point of identification, mutual recognition and respect within and through difference. Getting over fear has enabled much Black feminist scholarship on 'mixed race', Black women's bodies, 'race' performativity, Black Nationalism, Black women's sexualities and 'raced' gender identifications within academia.

The example of Black feminist work on 'mixed race' women's identifications is a useful one to show the newness that enters the world if one breaks away from fear's attempts to silence dissent. To work on 'mixed race' from a point of view that does not begin from discourses of lack, pathology, 'being caught between two cultures', dysfunction, 'the tragic mulata' and melancholia, is to fly in the face of much academic and popular knowledge. This point of view remains the case even given Ann Phoenix and Barbara Tizard's (2005) seminal work in this area and work by Jayne Ifekwunigwe (1999), Suki Ali (2003), Jill Olumide (2002), as well as Miri Song and Peter Aspinall (2013). Further, to insist that 'mixed race' women do indeed assert their Black identifications is a source of unease for some who still insist that mixedness is the site of racial and political uncertainty because, of 'bad white/Black blood', the only authentic blackness is a darker skinned one and mixedness puts one's claim to a place within the African diaspora in doubt. What Black feminist work continues to show in the $21^{\text {st }}$ century is that Black politics still stalls on the fact of mixedness and will continue to do so until we remember Morrison's point that we should not replace one form of dominance with another. We must not act in and through dominance if our expectation, our hope, is that Black decolonial feminist politics will come into being in university spaces to form a bond between Black women academics.

Morrison's (1992:xiv) question, "What happens to the writerly imagination of a Black author who is at some level always conscious of representing one's own race to, or in spite of, a race of readers that understands itself to be 'universal' 
or race free?", has been an important one for the academy to consider. This is especially so, given the placement of writing from Black women and women of colour within the Women's and Gender Studies canon as representing only a 'race' point of view. This 'race' point of view is regarded as all that are Black women and women of colour are capable of contributing theoretically. Their/ our work is perceived to be too particularistic to be capable of the universality of white feminist theory. The work of Black women and women of colour in the academy, therefore, continues to be faced with the double burden of tokenism and representing 'the race'. What would be different if the Women's and Gender Studies community saw itself as part of a white supremacist racialising assemblage? This is not a new question, but maybe it now demands a new(er) answer based on a Black decolonial feminist imperative. Such an imperative stresses a disidentification (Muñoz,1999) from dominant knowledge and asks that we relinquish our most cherished categories for critique. Black feminists have already insisted on this decolonising (Tate, 2010) imperative as they have turned their critical gaze on blackness itself. In this endeavour, they have built on Morrison's question to ask: "What happens to the writerly imagination of a Black author who is at some level always conscious of representing one's own identifications and politics to, or in spite of, readers who consider themselves to be political and cultural guardians of authentic, universal blackness?"

Both these questions, one from Morrison and the other drawing from her work, are inseparable for Black decolonial feminist analysis. They are inseparable because they add a different nuance to the work that is done in the moment of writing that Morrison rightly sees as a moment of becoming. That is, specifically the moment of positioning oneself-as through writing. This means that we must rid ourselves of the politics of fear. That is, fear of Black ostracism and of being impolite to whiteness, must be shed in order that we theorise in ways that are meaningful to us. We are helped enormously in this endeavour, of course, by the data from research participants who engage with the intersections of blackness, mixedness, gender, class, age, ability and sexuality in ways often overlooked as they are too challenging for the white constructed taken-for-granteds of blackness, such as 'the angry Black woman'. There is, of course, also a politics of silencing which comes out of our own communities as a response to academic work that goes against the grain of the established terrain of blackness. Wherever silencing comes from, it is laced with negative affect intent on causing shame, guilt and fear. 


\section{SCHOLARLY ENGAGEMENT AND DECOLONISATION}

Representing 'the race' and writing about 'race' to a white readership shrouded in its "epistemologies of ignorance" (Mills, 1997), wilfully (un)aware of its own racedness, racialising assemblages and 'race' performativity (Tate, 2005) is different in terms of affect. Here I, for one, do not feel shame, guilt or fear but rather anger at being placed as the token 'race' representative. Allied with this is unease that my work might be misappropriated and used against the Black decolonial feministimperative. Thatis, an imperative to illustrate the racialising assemblages of 'whiteness as norm' within feminist and other academic writing, which still so often remains un-remarked. In choosing not to have my work read as representative of 'the race', I run the risk of it being undermined and negated as being 'non-academic' because, being Black, I choose to write about intersectional 'race' and racism. There is an interesting way in which being Black discredits you for some white feminist academics if your writing goes against the grain of what they see as the givens of 'race' and racism.

Going against the givens of the white feminist canon means that you are 'the angry Black woman' who refuses (the fallacy of) objectivity. Anger though is a catalyst for the critique that is necessary given that we still inhabit worlds in which "ignoring race is understood to be a graceful, even generous, liberal gesture" (Morrison, 1994:9). These are worlds in which racism disappears in the rarefied air of predominantly white universities (Tate, 2012). How is anger useful in such a 'brick wall' context? How can anger generate political action against 'brick walls' through channelling the erotic?

\section{USES OF ANGER: CHANNELLING THE EROTIC}

In The Cancer Journals, Audre Lorde (1980) sees herself as a warrior in her response to the pain of cancer and speaks out against the silence that pain and illness can produce when compounded by racism and sexism. Her cancer makes her aware of her body as an object, of its raced and gendered flesh. Pain's despair alienates her from her body. Pain's alienation enables her to see herself as if from a distance, as other to that body from which she has turned away (Scarry, 1985). In The Cancer Journals, Lorde's first chapter is "The transformation of silence into language and action”, where she writes about the activism initiated by her breast cancer diagnosis. She argues that words are a source of power to combat the lack of agency of a woman with cancer 
and the lack of agency of a Black woman in US America. She reflects on the removal of her right breast in terms of femininity, corporeality and pain. Lorde fears that the loss of her breast will also mean the loss of a sensual area of the body for connecting to women and experiencing her own sexuality, but sees herself as a plural subject rather than one defined solely by the pain of her cancer (Musser, 2014). It is this plurality which is significant here - too often, as Black women, we are solely defined by 'race' and are constructed as having no life outside of that worth noting, attending to or theorising about. We are still just an outside, a surface, with no inner life worthy of note (Gordon, 1997). However, Lorde insists on our plurality, a plurality in which we cannot be known only as and through the racialised skins we inhabit.

In Uses of the erotic: The erotic as power, Lorde (2007a) sees the erotic as a resource within us which is a power vested in our (un)recognised feeling. For her, if we recognise our deepest feelings, we begin to be dissatisfied with suffering, self-negation and their accompanying numbness, and then act against oppression. For our purposes here, this is a call to us to recognise the anger caused by our construction as 'the angry Black woman'. "Lorde equates the erotic with realizing oneself as a coherent subject. The project of selfhood as Lorde describes it is one of empowerment through affective transformation. Against suffering and self-negation, Lorde situates responsibility, selfhood and feeling" (Musser, 2014:147).

Black decolonial feminists have a responsibility to feel anger, but equally we must locate it as not being of us. Instead, we should note that institutional anger emanates from the actions of white supremacist feminism and heteropatriarchy. The Black decolonial feminist's responsibility to feel anger as not inherently of us, enables us to become Black women on our own terms even in conditions we did not choose. Feeling our political way through Lorde's erotic is not only about reinforcing subjectivity, but about the formation of community as the erotic exceeds the intersubjective space as affect (Musser, 2014). If we relate this to anger, we can see that it displaces strategic essentialism as the basis of identity and opens other political possibilities through the construction of communities of mutual relationality bonded by affect. Lorde speaks about this construction of communities through joy. Joy is something shared which can bridge physical, emotional, psychic and intellectual differences to create new understandings and lessen 


\section{SCHOLARLY ENGAGEMENT AND DECOLONISATION}

the threat of difference as communities are formed through affective flows (Musser, 2014). Although invariably seen as negative, anger works in the same way as we can see if we think about campaigns like \#BlackLivesMatter. Indeed, "Lorde's politics of the erotic can be understood as a response to the traumas of racism and discrimination that prevent the formation of community among [Black] women” (Musser, 2014:147). Lorde also sees blackness as an identity that crosses geo-political and historical boundaries and the community of Black women as facing "great vulnerability because of racism and patriarchy" (Musser, 2014:148). Lorde's initial reaction to racist and sexist injustice is anger alongside understanding that, while anger is active it can also be a divisive force in a community so that the erotic and its solidarity politics are vital for the survival of Black decolonial feminist community (Musser, 2014:148). Her step away from anger to action is shown for example in 'Eye to Eye' (Lorde, 2007b). Here she speaks of the need for empowerment and the feeling for a new community to form which bonds women together to repair the damage of heteropatriarchy and racism, and to develop new ways of being beyond those systems which oppress Black women. Thus, Lorde speaks of the emergence of agency through anger and pain.

\section{CONCLUSION: AGENCY'S EMERGENCE THROUGH ANGER-PAIN}

In 'Eye to Eye' Lorde (2007b:172) distinguishes between pain and suffering:

Pain is an event, an experience that must be recognized, named, and then used in some way in order for the experience to change, to be transformed into something else, strength or knowledge or action. Suffering on the other hand, is the nightmare reliving of unscrutinized and unmetabolized pain [My italics].

Pain is sharp and distinct, but suffering exists as an inescapable cycle (Musser, 2014; Gordon, 1997). This suffering is very much seen to be the basis of Black liberation thought in Caribbean and Africana philosophy (Gordon, 1997; Spillers, 2003). White feminist invocation of Black women's suffering essentialises the Black decolonial feminist subject as 'the angry Black woman'. Sara Ahmed (2010:67) usefully describes this invocation as producing tension outside of one's own body, thus: 
It is not just that feelings are 'in tension' but that the tension is located somewhere: in being felt by some bodies, it is attributed as caused by another body, who thus comes to be felt as apart from the group, as getting in the way of its organic enjoyment and solidarity.

Within academia white feminists feel 'the angry Black woman' that they themselves have constructed through their anti-Black woman epistemologies of ignorance. Thus, 'she' comes into being without any need for questioning, guilt or shame at their racism. This anger that they feel with eager expectancy is always the fault of that Black woman over their/my and her/my unending suffering because of a racism they cannot find in white psyches, societal structures, knowledges, institutions or relationalities. Racism's only location is in that 'chip on my/our shoulders' from which my/our anger emerges.

However, as we name anger and its emergence within university workplaces as not us and not from us, we produce a becoming other rather than the white fixity as 'thing' (Fanon, 1986) with which we have always been named. Naming psychic institutional pain as anger at racist injustice allows for agency, action and solidarity. In naming this institutional pain as anger, I alienate myself and other Black women academics from the centuries' old, enslavement inspired suffering of 'the angry Black woman', which encases us in predominantly white UK universities. As I make myself strange from her through the pain of my teeth grinding and my complaint, I become the self-constructed other of that enslavement/colonial stereotype. I become unrecognisable much as was the case for Spivak's (1984) subaltern subject. I negate psychic institutional pain as I envisage myself as other to that which I am interpellated as being, as I occupy that space of marginality feted by bell hooks (1992). I am angry, I hurt, I am in pain as I remake myself as I always knew I was. I engage in my remaking without the need for the gaze of recognition, friendship, solidarity, love, attention or regard from white supremacist feminists. I am no longer surrounded by the Fanonian (1986) mask of 'the angry Black woman'. I begin to show me in my wholeness, in my solitude, but none-the-less in my uniqueness as someone with a background, a past and a future.

As I write this, I see how easy it is to forget who we are as Black women academics because of psychic institutional pain within universities. My estrangement from 'the angry Black woman' rejects the peculiar technology of the self, enacted 


\section{SCHOLARLY ENGAGEMENT AND DECOLONISATION}

by white supremacist feminist projection of strangeness onto my body and psyche, a projection that denies that racism can be felt as pain. This denial is a rebuttal of the fact that my pain has an external source and is not caused by my deficiencies, my lack of meaning to the lives of others, my being not worthy of notice within the workings of white institutions.

Other Black women academics and I must fight against pain emptying us out and making us abject as we "shrink into [our] body" (Fournier, 2002:63). We must maintain the materials of ourselves and for ourselves even as pain intends to strip these from us. This is what Black decolonial feminist theory provides. It is not just theory but it is a practice of and for the self, a technology with which to continue being a warrior - a guerrilla fighter much like Jamaica's Nanny who fought British colonialism for decades until her betrayal by the men she led and her subsequent execution. Placing ourselves as agents means that we stop the psychic pain generated in university spaces from seeping into our flesh as it seeks to unmake our selves because pain unchecked "brings selfhatred, the hatred for a self that has been engulfed by and reduced to an abject body" (Fournier, 2002:66).

Our involvement in the world of the university as a workplace must be an affective one. It must be acknowledged that we feel and in turn that those feelings are important for how and who we can become as Black women. We must also remember that racism works insidiously to enact Black women's isolation from each other by mobilising (in)difference and hatred within universities. Indeed, hatred "is the affect that Lorde connects to inhabiting a white space, and it is pernicious because it is violent and individuating” (Musser, 2014:116). This is not to solely talk about Black women's pain as the embodiment of the contradictions and constraints under which women are placed in patriarchal systems, the expression of "body anger" (Fournier, 2002:56). Rather, it is about responding to the pain of racism from within feminism itself. This is an active response to pain which does not speak of being passive objects but agents for change as we use the anger we feel at social injustice for Black decolonial feminist transformation (Lorde, 2007c). To go back to Sylvia Wynter (2006), we cannot solve the issue of consciousness in terms of their body of knowledge. The task now is for us to continue to seek out our own, to continue building on the foundations which we already have within Black decolonial feminist thought and politics. 


\section{ACKNOWLEDGEMENTS}

A version of this chapter appears as, "Descolonizando a Raiva: teoria feminista negra e a práctica nas universidades do Reino Unido" in J. Bernardino-Santos,

R. Grosfoguel and N. Maldonado-Torres (eds.), Pensamento Afro-diasporico e Decolonidade. Belo Horizonte: Autentica. 


\section{SCHOLARLY ENGAGEMENT AND DECOLONISATION}

\section{REFERENCES}

Ahmed, S. 2006. The non-performativity of antiracism. Meridians: feminism, race, transnationalism, 7(1):104-126. https:// doi.org/10.2979/MER.2006.7.1.104

Ahmed, S. 2010. The Promise of Happiness. Durham: Duke University Press. https://doi.org/10.1215/9780822392781

Ahmed, S. 2012. On Being Included: Racism and Diversity in Institutional Life. Durham: Duke University Press. https://doi.org/10.1215/9780822395324

Ali, S. 2003. Mixed-Race, Post-Race: Gender, New Ethnicities and Cultural Practices. Oxford: Berg.

Brennan, T. 2004. The Transmission of Affect. Ithaca \& London: Cornell University Press.

Cheng, A.A. 2001. The Melancholy of Race: Psychoanalysis, Assimilation and Hidden Grief. Oxford: Oxford University Press.

Chevannes, B. 1994. Rastafari: Roots and Ideology. Syracuse: Syracuse University Press.

Espinosa Miñoso, Y. 2007. Escritos de Una Lesbiana Oscura: Reflexiones Criticas Sobre el Feminismo y Politica de Identidad en América Latina. Buenos Aires and Lima: En La Frontera. Available: www.reduii.org/cii/sites/ default/files/field/doc/Escritos\%20 de\%una\%20lesbiana\%20oscura.pdf [accessed 11 March 2017].

Fanon, F. 1986. Black Skins, White Masks. London: Pluto Press.
Fournier, V. 2002. Fleshing out Gender: Crafting Gender Identities on Women's Bodies. Body and Society, 8(2):55-77. https://doi. rg/10.1177/1357034X02008002004

Garvey, A.J. 2016. Garvey and Garveyism. Baltimore: Black Classic Press.

Glissant, E. 1997. Poetics of Relation. B. Wing (tr.). Ann Arbor: University of Michigan Press. https://doi.org/10.3998/ mpub.10257

Goldberg, D.T. 2015. Are We All Postracial Yet? Debating Race. Camsbridge: Polity Press.

Gordon, L.R. 1997. Her Majesty's Other Children: Sketches of Racism from a Neocolonial Age. Lanham: Rowman and Littlefield.

Gutíerrez Rodríguez, E. 2010. Migration, Domestic Work and Affect: A Decolonial Approach on Value and the Feminization of Labor. New York \& London: Routledge. https://doi. org/10.4324/9780203848661

Holland, S.P. 2012. The Erotic Life of Racism. Durham: Duke University Press. https://doi.org/10.1215/9780822395157

hooks, b. 1992. Black Looks: Race and Representation. Boston: South End Press.

Ifekwunigwe, J.O. 1999. Scattered Belongings: Cultural Paradoxes of Race, Nation and Gender. London: Routledge.

Lorde, A. 1980. The Cancer Journals. Argyle, NY: Spinsters Ink. 
Lorde, A. 2007a. Uses of the erotic: The erotic as power. In: Sister Outsider: Essays and Speeches. New York: Random House. pp.53-59.

Lorde, A. 2007b. Eye to Eye. In: Sister Outsider: Essays and Speeches. New York: Random House. pp.145-175.

Lorde, A. 2007c. Uses of anger: Women responding to racism. In: Sister Outsider: Essays and Speeches. New York: Random House. pp.124-133.

Mills, C. 1997. The Racial Contract. Ithaca: Cornell University Press.

Morrison, T. 1992. Playing in the Dark: Whiteness and the Literary Imagination. Cambridge: Harvard University Press.

Muñoz, J.E. 1999. Disidentifications: Queers of Color and the Performance of Politics. Minneapolis: University of Minnesota Press.

Musser, A.J. 2014. Sensational Flesh: Race, Power and Masochism. New York and London: New York University Press. https://doi.org/10.18574/ nyu/9781479891818.001.0001

Olumide, J. 2002. Raiding the Gene Pool: The Social Construction of Mixed Race. London: Pluto Press.

Phoenix, A. \& Tizard, B. 2005. Black, White or Mixed Race? Race and Racism in the Lives of Young People of Mixed Parentage. London: Routledge. https://doi.org/10.4324/9780203994290

Quijano, A. 2000. Coloniality of power, Eurocentrism and Latin America. Nepantla: Views from South, 1(3):533-558. Available: https://unc.live/2tOKLzo [accessed 9 September 2017].
Reddock, R. 2007. Diversity, difference and Caribbean feminism: The challenge of anti-racism. Caribbean Review of Gender Studies: A Journal of Caribbean Perspectives on Gender and Feminism, 1. Available: http://bit.ly/2GqfQzs [accessed 9 September 2017].

Rodney, W. 1986. The Groundings with My Brothers. London: Bogle-L'Ouverture Press Ltd.

Scarry, E. 1985. The Body in Pain: The Making and Unmaking of the World. Oxford: Oxford University Press.

Song, M. \& Aspinall, P. 2013. Mixed Race Identities. Basingstoke: Palgrave Macmillan. https://doi. org/10.1057/9781137318893

Spillers, H. 2003. Mama's baby, Papa's maybe: An American grammar book. In: H. Spillers (ed.), Black and White in Color: Essays on American Literature and Culture. Chicago: University of Chicago Press. pp.203-229.

Spivak, G. 1984. Can the subaltern speak? In: P. Williams \& L. Chapman (eds.), Colonial Discourse and Post-colonial Theory: A Reader. Hemel Hempstead: Simon and Schuster International Group. pp.66-111.

Tate, S.A. 2005. Black Skins, Black MasksHybridity, Dialogism, Performativity. Aldershot: Ashgate.

Tate, S.A. 2010. 'Not all the women want to be white'. In: E. Gutíerrez Rodríguez, M. Boatcă \& S. Costa (eds.), Decolonizing European Sociology. Aldershot: Ashgate. pp.195-223. 


\section{SCHOLARLY ENGAGEMENT AND DECOLONISATION}

Tate, S.A. 2012. Supping it: Racial affective economies and the epistemology of ignorance. In: M. Christian (ed.), Integrated but Unequal: Black Faculty in Predominantly White Spaces. New Jersey: Africa World Press.

Tate, S.A. \& Wahidin, A. 2013. Extraneare: Pain, loneliness and the incarcerated female body. Illness, Crisis and Loss, 21(3):203-217. https://doi.org/10.2190/ IL.21.3.c

Thomas, D. 2004. Modern Blackness: Nationalism, Globalization and the Politics of Culture in Jamaica. London and Durham: Duke University Press. https://doi.org/10.1215/9780822386308
Thomas, G. 2006. PROUD FLESH Inter/ Views: Sylvia Wynter. PROUDFLESH: A New Afrikan Journal of Culture, Politics and Consciousness: Issue 4. Available: http://bit.ly/37H77Fr [accessed 3 April 2017].

Truillot, M. 1995. Silencing the Past: Power and the Production of History. Boston: Beacon Press.

Weheliye, A.G. 2014. Habeas Viscus: Racializing Assemblages, Biopolitics and Black Feminist Theories of the Human. Durham: Duke University Press. https://doi.org/10.1215/9780822376491 